\title{
The Effect of Leptin on Bone - An Evolving Concept of Action
}

\author{
V. CIRMANOVÁ ${ }^{1}$, M. BAYER ${ }^{2}$, L. STÁRKA ${ }^{1}$, K. ZAJÍČKOVÁ ${ }^{1}$ \\ ${ }^{1}$ Institute of Endocrinology, Prague and ${ }^{2}$ Department of Pediatrics, Charles University in Prague, \\ Faculty of Medicine in Hradec Králové, Czech Republic
}

Received November 12, 2007

Accepted January 28, 2008

On-line February 13, 2008

\section{Summary}

Leptin, a cytokine-like hormone secreted by adipocytes, is known to regulate food intake but has also emerged as a significant factor in the regulation of bone mass. In humans, states of energy deprivation with low serum leptin have been associated with low bone mass. In mice, leptin deficiency led to increased trabecular bone mass with overall decrease in cortical bone. Leptin regulates bone metabolism indirectly in the hypothalamus thereby activating the sympathetic nervous system (SNS). In addition to the SNS, leptin also interacts with various hypothalamic neuropeptides, such as cocaine- and amphetamineregulated transcript, neuropeptide $\mathrm{Y}$ and/or neuromedin $\mathrm{U}$, which might modulate the effects of leptin on bone. In osteoblasts sympathetic signaling is further gated by the transcriptional factors called molecular clock. As a result, bone loss is accelerated showing that the central effect of leptin seems to be antiosteogenic. Additionally, leptin has a direct anabolic effect within the bone driving the differentiation of bone marrow stem cells into the osteoblastic cell lineage. Besides the interaction between the central and peripheral pathways, the overall effect of leptin on bone might be bimodal depending on leptin serum concentrations. Regulatory pathways triggering osteoblast activity might open new possibilities for anabolic treatment of osteoporosis.

\section{Key words}

Leptin • Bone • Osteoblast • Adipocyte • Sympathetic Nervous System • Neuropeptides

\section{Corresponding author}

V. Cirmanová, Institute of Endocrinology, Národní trída 8, 11694

Prague 1, Czech Republic. E-mail: vcirmanova@endo.cz
Leptin, a fat-derived cytokine-like hormone, was discovered in 1994 by Friedman and colleagues (Zhang et al. 1994). A 16-kDa hormone, encoded by the OB gene, is predominantly expressed in adipose tissue (Zhang et al. 2005) and circulates as a free and as a protein-bound entity. The protein sequence of leptin is considerably conserved among different species, with the highest homology found between human and chimpanzee molecules (Zhang et al. 2005). According to structural studies leptin belongs to the growth hormone four-helical cytokine subfamily. The leptin receptor was identified in the $\mathrm{db}$ locus of mouse chromosome 4 (Tartaglia et al. 1995). As a member of the IL-6 receptor family, the leptin receptor contains an extracellular-binding domain, a single transmembrane domain and a cytoplasmatic signaling domain (Tartaglia et al. 1995). Intracellular signaling is mediated through a non-covalently associated tyrosine kinase of the JAK kinase family (Zhang et al. 2005). Alternate gene splicing results in five known isoforms of the leptin receptor. The longest form of the receptor $(\mathrm{ObR})$ is the only isoform capable of complete signal transduction. Conversely, the shorter isoforms of the leptin receptor have been suggested to participate in leptin clearance and/or to facilitate transport of leptin across the blood-brain barrier (Zhang et al. 2005).

Food intake and energy expenditure are controlled by leptin through an interaction with various neuropeptides in the hypothalamus. Neuropeptide $\mathrm{Y}$ (NPY) and agouti-related peptide (AGRP) expressions are inhibited, whereas pro-opiomelanocortin (POMC) expression is stimulated by leptin with increased food intake (Wardlaw 2001, Patel and Elefteriou 2007). Moreover, leptin interacts with neuromedin U (NMU); a 
novel and recently identified hypothalamic neuropeptide involved also in the regulation of appetite and locomotor activity (Sato et al. 2007). Besides energy metabolism, leptin demonstrates pleiotropic effects in such areas as hematopoesis, blood pressure, T lymphocyte function, reproduction and bone mass regulation (Zhang et al. 2005, Sirotkin et al. 2007).

Obese patients have a higher risk of coronary artery disease, but a lower risk of osteoporosis. Conversely, moderate weight loss due to dieting in obese women leads to bone loss (Ricci et al. 2001). Six months on a diet resulting in $5.5 \%$ weight loss has been associated with a $4.2 \%$ decrease in whole body bone mineral content (BMC) and a $4.0 \%$ decrease in the hip in women (Jensen et al. 2001). A study of 130 young women with anorexia has shown a high prevalence of fractures and low bone mineral density (BMD). Regardless of history of estrogen use, weight was the strongest predictor of BMD at various skeletal sites further demonstrating the connection between low weight and bone mineral density (Grinspoon at al. 2000). Several endocrine and paracrine factors play a role in the fat-bone relationship. Adipose tissue is a source of estrogens and a high fat mass is associated with elevated insulin levels (Grodin et al. 1973, Reid 2002). Both hormones contribute to bone formation. A number of local cytokines secreted by the adipose tissue, including leptin, have also been related to BMD variations (Reid 2002). Leptin represents one of the important functional connections between fat and bone.

\section{Leptin, mice knockout models and bone}

Leptin-deficient (ob/ob) and leptin receptordeficient $(\mathrm{db} / \mathrm{db})$ mice are obese and hypogonadal (Ducy et al. 2000a,b). Initial works on these mouse mutants have also suggested high bone mass due to increased bone formation. Intracerebroventricular (icv) infusion of leptin caused bone loss in both leptin-deficient and wild type (WT) mice. Based on these experiments leptin is considered to be a potent inhibitor of bone formation acting through the central nervous system. Further studies have, however, demonstrated that the effect of altered leptin action on bone was not uniform throughout the skeleton and varied significantly between the axial and appendicular regions (Hamrick 2004). Ob/ob mice had significantly increased vertebral length, lumbar BMD and trabecular bone volume compared to WT mice. In contrast to the findings at the lumbar spine, leptin deficient mice had significantly shorter femora with lower BMD, cortical thickness and trabecular bone volume compared to lean WT mice. The quadriceps muscle volume of the ob/ob mice was $40 \%$ less than those of controls. Higher adipocyte number was detected in the femora in leptin-deficient mice. Peripheral leptin administration corrected both the bone marrow adipocyte size and number in ob/ob mice (Hamrick et al. 2005). The muscle hypoplasia and/or increased bone marrow adipogenesis were found to contribute to the discrepant effect of leptin deficiency with respect to cortical and trabecular bone compartments. The lumbar spine is mainly constituted of trabecular bone, whereas cortical bone prevails at the appendicular skeleton contributing to $80 \%$ of the total bone mass (Hamrick 2007, Baldock et al. 2006).

Leptin might modulate sex-dependent skeletal dimorphism. When leptin-deficient male and female mice have been compared to their WT counterparts, a loss of sex-specific bone characteristics was documented in the male leptin knockout mice (Wang et al. 2007). Significant reductions in the periosteal and endosteal circumference and/or total BMC at the femoral midshaft have been seen in male but not in female ob/ob mice. The loss of sex-related differences in these bone parameters together with 5-fold higher serum free testosterone levels in adult male ob/ob mice might suggest impaired androgen signaling in bone. Leptin might, therefore, function as an important modulator of androgens action on bone.

\section{Leptin, sympathetic nervous system and bone}

In order to evaluate its central effect, leptin was injected into the brain in the form of an icv infusion at a rate that did not result in any detectable leak of leptin into general circulation (Ducy et al. 2000a,b, Karsenty 2006). Bone loss occurred in both wild-type mice and leptindeficient mice confirming that bone mass is partly regulated via the central, hypothalamic relay (Ducy et al. 2000). However, bone formation was inhibited at lower doses of leptin than those necessary to cause the loss of body weight.

Ob/ob mice have low sympathetic activity, which led to the assumption that the central effect of leptin on bone is mediated by the sympathetic nervous system (SNS) (Takeda et al. 2002) (Fig. 1a). Restoration of sympathetic activity in leptin-deficient mice led to a $45 \%$ decrease in bone mass without affecting appetite or 
reproduction. On the other hand, a $\beta_{2}$-adrenergic receptor $\left(\beta_{2}-\mathrm{AR}\right)$ knockout model had high bone mass. Unlike ob/ob mice, $\beta_{2}$-AR-deficient mice had no other endocrine abnormalities affecting bone metabolism, which further supports the link between leptin and SNS. Noradrenalin inhibited bone formation by binding to $\beta_{2}$-ARs on osteoblasts (Ducy et al. 2000a,b). Conversely, inhibition of beta-adrenergic neurons resulted in leptin-resistant high bone mass.

In addition, bone loss induced by ovariectomy in rats was prevented in part by the administration of betablocker propranolol (Takeda et al. 2002). Patients taking beta-blockers for hypertension had lower risk of fractures (Schlienger et al. 2004, Pasco 2004). In a study by Reid et al. (2005) women treated with beta-blockers had higher BMD. However, statistical significance was eliminated after the adjustment for body weight. The results of the few observational studies remain, therefore, contradictory. The potentially protective effect of betablockers on the skeleton does not seem to be mediated through $\beta_{2}$-adrenergic signaling on osteoblasts because the vast majority of hypertensive patients are treated by selective $\beta_{1}$-blockers (Hamrick and Ferrari 2007). Although $\beta_{1}$-AR-deficient mice have normal bone phenotype, mice deficient for both the $\beta_{1}$ - and $\beta_{2}$-ARs show lower cortical bone volume. These double $\beta$-AR knockouts also show low circulating levels of IGF-I. $\beta_{1}$-adrenergic stimulation may therefore activate the growth hormone/IGF-I axis and thereby contribute to cortical bone mass maintenance (Hamrick and Ferrari 2007, Patel and Elefteriou 2007).

\section{Leptin and the molecular clock}

In osteoblasts, sympathetic signaling is further modulated by the molecular clock composed of the transcriptional factors Per and Cry (Patel and Elefteriou 2007) (Fig. 1b). Molecular clock gene products contribute to daily variation in bone marrow proliferation. Mice lacking molecular gene Per2 were found to have high bone mass phenotype due to increased bone formation rate (Fu et al. 2005). Icv leptin infusion did not reverse the high bone mass phenotype in Per2-deficient mice. The data have supported the hypothesis that the molecular clock acts downstream of $\beta_{2}$-AR to gate sympathetic signaling in osteoblasts (Karsenty 2006).

In addition to bone formation, sympathetic signaling also regulates bone resorption. Isoproterenol, a surrogate of sympathetic signaling, increases expression of RANKL in osteoblasts that results in the activation of osteoclastogenesis (Karsenty 2006).

\section{Leptin-regulated hypothalamic neuropeptides}

In addition to leptin, other hypothalamic peptides such as neuromedin U (NMU) and neuropeptide Y (NPY) seem to be another link between food intake and bone metabolism. Neuromedin $\mathrm{U}$, an anorexigenic neuropeptide, has been identified as a potent regulator of bone formation (Hanada et al. 2004). Neuromedin Udeficient mice (NMU-/-) showed a $30 \%$ increased bone formation with high bone mass including both trabecular and cortical bone compared to WT mice (Sato et al. 2007). The bone phenotype was more prominent in male NMU-/- mice. Beta-adrenergic agonist isoprote-renol inhibited bone formation in WT mice, whereas in it had no effect on osteoblast activity neuromedin U-deficient mice. Leptin icv infusions did not lead to inhibition of bone formation in NMU-deficient mice in spite of leptininduced weight loss. Moreover, expression of the molecular clock genes (Per1/Per2) has been downregulated in NMU-/- mice. Thus, NMU, acting through the CNS, affects the molecular clock in bone by an unidentified mechanism and represents the first central mediator of leptin-dependent regulation of bone mass (Sato et al. 2007) (Fig. 1). Whereas a natural agonist for the NMU receptor (NMU-R) decreased bone mass in WT mice, a NMU-R antagonist may be a candidate for the treatment of bone-loss disorders without inducing body weight gain (Sato et al. 2007).

Continuous icv infusions of NPY decreased bone volume in WT mice (Ducy et al. 2000a,b). NPY represents another hypothalamic inhibitor of bone formation. Mice lacking NPY2 receptors had both higher trabecular and cortical bone mass compared to WT mice (Baldock et al. 2006). Hypothalamic-specific deletion of Y2 receptors reproduced the bone phenotype, supporting the central mechanism of the Y2 signaling (Fig. 1). Central leptin signaling inhibits NPY production in leptin-responsive NPY neurons (Allison et al. 2007). Modulation of the NPY action stimulates osteoblast activity, demonstrating this pathway to be anabolic (Baldock et al. 2006, Patel and Elefteriou 2007).

Leptin stimulates the expression of another hypothalamic neuropeptide, cocaine- and amphetamineregulated transcript (CART) (Kristensen et al. 1998). Mice lacking CART have low bone mass due to an increase in bone resorption stimulated by RANKL 
(Elefteriou et al. 2005). Unlike ob/ob mice, CARTdeficient mice are fertile and have a normal appetite. On the other hand, mice models with CART overexpression, such as melanocortin 4 receptor-deficient mice, have high bone mass (Elefteriou et al. 2005). Leptin seems to regulate bone resorption in two opposite ways. First, leptin stimulates bone resorption through SNS and RANKL pathway. Second, leptin inhibits bone resorption through enhanced CART expression (Karsenty 2006) Particular steps in the signaling pathway between the hypothalamic CART and bone remodeling remain to be elucidated (Fig. 1).

\section{Direct leptin effects in bone microenvironment}

Connection between fat and bone may occur locally within the bone microenvironment. Bone marrow stromal cells (BMSC) can differentiate into either adipocytes or osteoblast cell lineage. One of the important factors driving the differentiation of the BMSC into osteoblasts is transcription factor Cbfa1 (core binding factor 1) (Nuttall et al. 2000). Leptin also inhibits adipogenesis differentiation of BMSC and stimulates differentiation of osteoblasts (Thomas et al. 2001) (Fig. 1b). Moreover, leptin administered peripherally resulted in adipose tissue apoptosis in mice (Hamrick et al. 2005). On the other hand, mature adipocytes were able to inhibit osteoblastic proliferation and action if both cell types were co-cultured together. This suppressive effect might be mediated through a factor secreted by adipocytes (Maurin et al. 2000). States with low bone mass, such as postmenopausal osteoporosis and glucocorticoids-induced osteoporosis, are often accompanied by the increased bone marrow adipogenesis. Wang et al. (2000) have demonstrated in culture and in a mouse model that administration of dexamethasone enhanced adipogenesis, while differentiation of BMSC to osteoblasts was suppressed. In osteoporotic women the number of adipocytes in the bone marrow was also higher than in women with normal BMD (Justesen et al. 2001). Glucocorticoids are, however, able to significantly stimulate leptin synthesis and secretion directly in the adipose tissue (Leal-Cerro et al. 2001). On one hand, bone marrow adipocytes may serve as a direct source of leptin, which can stimulate a differentiation of BMSC into the osteoblasts. On the other hand, some experiments have shown that very high leptin levels led to BMSC apoptosis (Kim et al. 2003). These tissue culture experiments support the bimodal effect of leptin within the bone microenvironment depending on the local, paracrine leptin concentration.

The initial studies by Ducy et al. (2000a,b) have not disclosed any long isoforms of the leptin receptors (Ob-R) on osteoblasts. They have therefore reported that leptin acted centrally as a very potent inhibitor of bone formation. Although the long isoform of Ob-R is abundantly expressed in the hypothalamus, particularly in areas involved in the energy balance, the presence of the leptin receptors has been detected in a large number of peripheral tissues (Zhang et al. 2005). BMSC, osteoblasts, osteoclasts and chondrocytes also express leptin receptors (Thomas et al. 1999). In osteoblasts, leptin acts through the osteoprotegerin (OPG)/RANKL (Receptor Activator for Nuclear factor $\kappa \mathrm{B}$ Ligand) signaling pathway (Fig. 1b). Treatment with leptin changes the OPG/RANKL expression profile favoring OPG (Holloway et al. 2002). Consequently, osteoclastogenesis is very likely suppressed by leptin through the OPG/RANKL pathway. In agreement with the previous findings, Burguera et al. (2001) have shown that administration of leptin reduced ovariectomyinduced bone loss in rats by increasing osteoprotegerin mRNA in osteoblasts. Cornish et al. (2002) have found that leptin given peripherally increased bone strength in mice and also increased proliferation of osteoblasts in vitro. Direct peripheral action of leptin on bone seems to be, therefore, rather anabolic in contrast to central antiosteogenic effect.

\section{Dose dependent effects of leptin on bone}

In tail-suspended rats, a model of disuse-induced osteoporosis, leptin administered intraperito-neally at low or high doses led to different bone phenotypes (Martin et al. 2007). A low leptin dose compensated the decrease in serum leptin levels observed with suspension and prevented induced bone loss at both the trabecular and cortical compartments. In contrast, a high dose of leptin inhibited femoral bone growth and reduced bone mass by decreasing bone formation rate and increasing bone resorption. Moreover, a high dose of leptin induced a decrease in body-weight, abdominal fat mass and serum IGF-I levels. A deteriorated bone phenotype in high-dose leptin-treated rats has been attributed in part to a leptininduced energy imbalance with related hormonal changes. These experiments have demonstrated that positive and negative leptin effects on bone depend on a bimodal threshold triggered by leptin serum concentration. 


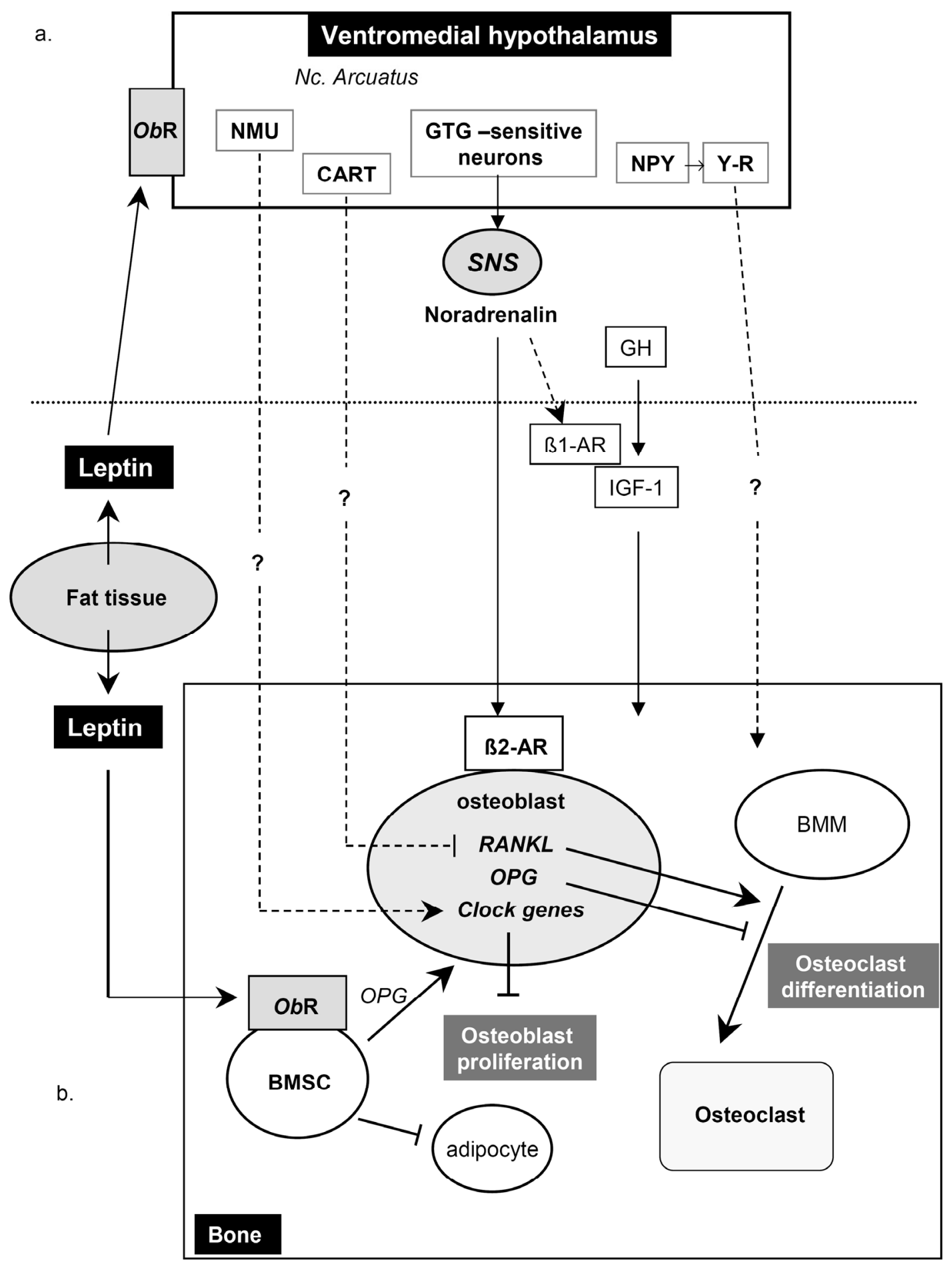

Fig. 1. Central (1a) and peripheral (1b) concept of leptin-dependent regulation of bone mass. 1a. In the VMH leptin binds to the leptin receptors (ObR). In the nucleus arcuatus CART expression is stimulated by leptin. Via undefined intermediary steps RANKL expression is decreased resulting in inhibition of bone resorption. Through GTG-sensitive neurons leptin activates sympathetic nervous system. Noradrenaline binds to $\beta_{2}$-AR on the osteoblasts. The effect of sympathetic signaling is further gated by transcriptional factors called molecular clock and osteoblast proliferation is thus inhibited. Molecular clock is also under the control of NMU - another hypothalamic peptide stimulated by leptin. In osteoblast SNS also stimulates RANKL expression and thus activates osteoclastogenesis. 1b. Leptin can affect bone metabolism also directly by binding to the leptin receptor on BMSC. As a result, BMSC differentiate to osteoblasts, whereas adipogenesis is inhibited. In BMSC and in osteoblasts leptin stimulates production of OPG and inhibits secretion of RANKL. Osteoclast differentiation from bone marrow monocytes is therefore inhibited.

$\beta$-AR - beta-adrenergic receptor, BMM - bone marrow monocytes, BMSC - bone marrow stromal cells, CART - cocaine and amphetamine regulated transcript, GH - growth hormone, GTG-sensitive neurons - gold-thioglucose-sensitive neurons, IGF-1 - insulinlike growth factor 1 , Mc4R - melanocortin 4 receptor, NMU - neuromedin U, NPY - neuropeptide Y, ObR - leptin receptors, OPG osteoprotegerin, RANKL - Receptor Activator for Nuclear Factor KB Ligand, SNS - sympathetic nervous system, VMH - ventromedial hypothalamus, Y-R - receptors for NPY, ? - question marks indicate undefined intermediary steps that remain to be discovered. 


\section{Serum leptin correlations with bone density in clinical studies}

Yamauchi et al. (2001) reported that plasma leptin levels were positively correlated with bone mineral density (BMD) values. Multiple regression analysis revealed that the relationship was also significant for whole body and femoral neck BMD even after the adjustment for percentage of body fat and for age. Moreover, leptin levels in plasma, but not in body fat tissue, were significantly lower in women with vertebral fractures than in those without fractures. Thomas et al. (2001) have documented that serum leptin correlated with BMD in women but not in men. Sato et al. (2001) have found a positive correlation between serum leptin and calcaneus BMD in men, but the relationship became inverse when adjusted for body weight. Pasco et al. (2001) have demonstrated a significant positive association between BMD and serum leptin in non-obese women. In a small study, Iwamoto et al. (2000) have found correlations between serum leptin and bone remodelling markers only in premenopausal women. Correlations between BMD of the pelvis and/or left leg were weak. Moreover, there was no relationship between serum leptin and whole body BMD. In a cohort of young men, leptin levels correlated with cortical circumference of the tibia as measured by quantitative computer tomography (QCT) (Lorentzon et al. 2006). Although a number of studies have examined the relationship between serum leptin and BMD in various cohorts, the results remain conflicting. This fact reflects the complexity of the leptin effect on bone with respect to gender, specific bone compartments and/or skeletal regions.

\section{Leptin resistance and bone - possible therapeutical implications}

The effect of leptin is curtailed with increased age and higher BMI in both humans and laboratory animals in spite of high serum leptin levels (Hamrick 2007). Under-responsiveness to leptin, or leptin resistance, is mediated either by impaired transport of leptin through the blood-brain barrier, lower expression of leptin receptors and/or by the inhibition of the intracellular leptin signaling (Munzberg et al. 2005). In plasma, leptin is bound to soluble leptin receptor (SLR), the product of an alternate splicing of leptin receptor mRNA or proteolytic cleavage (Zhang et al. 2005).
Whereas serum leptin levels correlate positively with BMI, SLR is correlated negatively (Zhang et al. 2005, Anderlová et al. 2006). The inverse relationship between SLR and BMI reflects a feedback regulation between the body weight and leptin or leptin receptor expressions.

Due to leptin resistance, the potential utility of leptin is limited only to the states of energy deprivation with leptin deficiency, such as exercise-induced hypothalamic amenorrhea, anorexia nervosa, and weight loss. Leptin may therefore stimulate bone formation only at younger ages, in individuals with very low BMI and/or with very low leptin serum levels (Hamrick 2007). Women with hypothalamic amenorrhea induced either by exercise or by low body weight had very low serum leptin levels (Welt et al. 2004). Treatment with recombinant human leptin for three months led to an increase of osteocalcin, bone alkaline phosphates and IGF-1, whereas urinary N-telopeptide did not change. Leptin administration in individuals with leptin deficiency appeared to improve the growth hormone axis and markers of bone formation as documented in a recent interventional trial (Welt et al. 2004).

\section{Conclusions}

An increasing number of published papers on leptin and bone revealed a very complex relationship between this fat-derived hormone, bone and the central nervous system. Based on the current state of knowledge, we can cautiously draw a few conclusions about leptin and bone.

First, in humans, the states of energy deprivation with low serum leptin levels have been associated with low bone mass (Hamrick 2007). In leptin-deficient mouse models, however, bone mass varied significantly between the axial and appendicular regions (Hamrick 2004). Lumbar spine BMD was high due to increased trabecular bone mass in ob/ob mice, whereas appendicular BMD was lower due to overall decrease in cortical bone. According to so-called "adaptive theory", preserved trabecular bone may serve as a source of minerals to maintain calcium-phosphate homeostasis in states of caloric restriction (Khosla 2002).

Second, leptin regulates bone formation indirectly by binding to its receptors located in the hypothalamus and thereby activating SNS (Karsenty 2006). In addition to SNS, leptin also interacts with various hypothalamic neuropeptides. Sympathetic signaling in osteoblasts is further gated by transcriptional 
factors called molecular clock (Martin et al. 2007). Expression of the molecular clock genes is partly under the control of neuromedin $\mathrm{U}$, an anorexigenic hypothalamic neuropeptide (Sato et al. 2007). Bone loss is accelerated in this way and the central effect of leptin seems to be rather antiosteogenic. On the other hand, leptin stimulates expression of CART in the hypothalamus resulting in high bone mass phenotype due to decreased bone resorption (Elefteriou et al. 2005).

Third, leptin additionally has a direct anabolic effect within the bone microenvironment. Differentiation of BMSC into the osteoblastic cell lineage and adipocyte apoptosis is stimulated by leptin treatment (Thomas et al. 1999, Hamrick 2007). Besides the interaction between the central and peripheral pathways, the overall effect of leptin on bone seems to be also modulated by its serum concentration (Martin et al. 2007). Whereas initial increases in leptin stimulate bone formation, higher levels of leptin result in its inhibition.

Resistance to endogenous leptin increases both with age and BMI (Hamrick 2007, Munzberg et al. 2005). Hence, the majority of postmenopausal women with normal food intake would be probably insensitive to leptin treatment. The potential utility of leptin as a therapy for bone loss would be preserved in conditions of leptin deficiency and energy deprivation, such as food restriction, exercise-induced hypothalamic amenorrhea, anorexia nervosa, and perhaps weight loss (Hamrick and Ferrari 2007).

Important results from mouse knock-out or transgenic models have to be cautiously correlated with the human physiology. Although a lot of intermediate steps between nutrition and bone metabolism still remain to be elucidated, leptin represents an important functional connection. The discovery of novel regulatory pathways triggering osteoblast activity might open new possibilities for anabolic treatment of osteoporosis.

\section{Conflict of Interest}

There is no conflict of interest.

\section{Acknowledgements}

Grant NR/9055-4 from the Internal Grant Agency of the Czech Ministry of Health supported the work.

\section{References}

ALLISON SJ, BALDOCK PA, HERZOG H: The control of bone remodeling by neuropeptide Y receptors. Peptides 28: 320-325, 2007.

ANDERLOVÁ K, KŘEMEN J, DOLEŽALOVÁ R, HOUSOVÁ J, HALUZÍKOVÁ D, KUNEŠOVÁ M, HALUZÍK $\mathrm{M}$ : The influence of very-low-calorie-diet on serum leptin, soluble leptin receptor, adiponectin and resistin levels in obese women. Physiol Res 55: 277-283, 2006.

BALDOCK PA, ALLISON S, MCDONALD MM, SAINSBURY A, ENRIQUEZ RF, LITTLE DG, EISMAN JA, GARDINER EM, HERZOG H: Hypothalamic regulation of cortical bone mass: opposing activity of Y2 receptor and leptin pathways. $J$ Bone Miner Res 21: 1600-1607, 2006.

BURGUERA B, HOFBAUER LC, THOMAS T, GORI F, EVANS GL, KHOSLA S, RIGGS BL, TURNER RT: Leptin reduces ovariectomy-induced bone loss in rats. Endocrinology 142: 3546-3553, 2001.

CORNISH J, CALLON KE, BAVA U, LIN C, NAOT D, HILL BL, GREY AB, BROOM N, MYERS DE, NICHOLSON GC, REID IR: Leptin directly regulates bone cell function in vitro and reduces bone fragility in vivo. J Endocrinol 175: 405-415, 2002.

DUCY P, SCHINKE T, KARSENTY G: The osteoblast: a sophisticated fibroblast under central surveillance. Science 289: 1501-1504, 2000a.

DUCY P, AMLING M, TAKEDA S, PRIEMEL M, SCHILLING AF, BEIL FT, SHEN J, VINSON C, RUEGER JM, KARSENTY G: Leptin inhibits bone formation through a hypothalamic relay: a central control of bone mass. Cell 100: 197-207, 2000b.

ELEFTERIOU F, AHN JD, TAKEDA S, STARBUCK M, YANG X, KIU X, KONDO H, RICHARDS WG, BANNON TW, NODA M, CLEMENT K, VAISSE C, KARSENTY G: Leptin regulation of bone resorption by the sympathetic nervous system and CART. Nature 434: 514-520, 2005.

FU L, PATEL MS, BRADLEY A, WAGNER EF, KARSENTY G: The molecular clock mediates leptin-regulated bone formation. Cell 122: 803-815, 2005. 
GRINSPOON S, THOMAS E, PITTS S, GROSS E, MICKLEY D, MILLER K, HERZOG D, KLIBANSKI A: Prevalence and predictive factors for regional osteopenia in women with anorexia nervosa. Ann Intern Med 133: 790-794, 2000.

GRODIN J, SIITERI P, MACDONALD P: Source of estrogen production in postmenopausal women. J Clin Endocrinal Metab 36: 207-214, 1973.

HAMRICK MW: Leptin, bone mass, and the thrifty phenotype. J Bone Miner Res 19: 1607-1611, 2004.

HAMRICK MW: Leptin and bone: a consensus emerging? IBMS BoneKEy 4: 99-107, 2007.

HAMRICK MW, FERRARI SL: Leptin and the sympathetic connection of fat to bone. Osteoporos Int 2007 [In press].

HAMRICK MW, DELLA-FERA MA, CHOI YH, PENNINGTON C, HARTZELL D, BAILE CA: Leptin treatment induces loss of bone marrow adipocytes and increases bone formation in leptin-deficient $o b / o b$ mice. $J$ Bone Miner Res 20: 994-1000, 2005.

HANADA R, TERANISHI H, PEARSON JT, KUROKAWA M, HOSODA H, FUKUSHIMA N, FUKUE Y, SERINO R, FUJIHARA H, UETA Y, IKAWA M, OKABE M, MURAKAMI N, SHIRAI M, YOSHIMATSU H, KANGAWA K, KOJIMA M: Neuromedin U has a novel anorexigenic effect independent of the leptin signaling pathway. Nat Med 10: 1067-1073, 2004.

HOLLOWAY WR, COLLIER FM, AITKEN CJ, MYERS DE, HODGE JM, MALAKELLIS M, GOUGH TJ, COLLIER GR, NICHOLSON GC: Leptin inhibits osteoclast generation. J Bone Miner Res 17: 200-209, 2002.

IWAMOTO I, DOUCHI T, KOSHA S, MURAKAMI M, FUJINO T, NAGATA Y: Relationships between serum leptin level and regional bone mineral density, bone metabolic markers in healthy women. Acta Obstet Gynecol Scand 79: 1060-1064, 2000.

JENSEN LB, KOLLERUP G, QUAADE F, SORENSEN OH: Bone minerals changes in obese women during a moderate weight loss with and without calcium supplementation. J Bone Miner Res 16: 141-147, 2001.

JUSTESEN J, STENDERUP K, EBBESEN EN, MOSEKILDE L, STEINICHE T, KASSEM M: Adipocyte tissue volume in bone marrow is increased with aging and in patients with osteoporosis. Biogerontology 2: 165-71, 2001.

KARSENTY G: Convergence between bone and energy homeostasis: leptin regulation of bone mass. Cell Metabolism 4: 341-348, 2006.

KHOSLA S: Leptin-central or peripheral to regulation of bone metabolism? Endocrinology 143: 4161-4164, 2002.

KIM GS, HONG JS, KIM SW, KOH JM, AN CS, CHOI JY, CHENG SL: Leptin induces apoptosis via ERK/cPLA2/cytochrome c pathway in human bone marrow stromal cells. J Biol Chem 13: 21920-21929, 2003.

KRISTENSEN P, JUDGE ME, THIM L, RIBEL U, CHRISTJANSEN KN, WULFF BS, CLAUSEN JT, JENSEN PB, MADSEN OD, VRANG N, LARSEN PJ, HASTRUP S: Hypothalamic CART is a new anorectic peptide regulated by leptin. Nature 393: 72-76, 1998.

LEAL-CERRO A, SOTO A, MARTÍNEZ MA, DIEGUEZ C, CASANUEVA FF: Influence of cortisol status on leptin secretion. Pituitary 4: 111-116, 2001.

LORENZTON M, LANDIN K, MELLSTROM D, OHLSSON C: Leptin is a negative independent predictor of areal BMD and cortical bone size in young adult Swedish men. J Bone Miner Res 21: 1871-1878, 2006.

MARTIN A, DAVID V, MALAVAL L, LAFAGE-PROUS MH, VICO L, THOMAS T: Opposite effects of leptin on bone metabolisms: a dose-dependent balance related to energy intake and IGF-I pathway. Endocrinology 148 : 3419-25, 2007.

MAURIN AC, CHAVASSIEUX PM, FRAPPART L, DELMAS PED, SERRE CM, MEUNIER PJ: Influence of mature adipocytes on osteoblast proliferation in human primary co cultures. Bone 26: 485-489, 2000.

MUNZBERG H, BJORNHOLM M, BATES SH, MYERS MG Jr: Leptin receptor action and metabolisms of leptin resistance. Cell Mol Life Sci 62: 642-652, 2005.

NUTTALL ME, GIMBLE JM: Is there a therapeutic opportunity to either prevent or treat osteopenic disorders by inhibiting marrow adipogenesis? Bone 27: 177-184, 2000.

PASCO JA: Beta-adrenergic blockers reduce the risk of fracture partly by increasing bone mineral density: Geelong Osteoporosis Study. J Bone Miner Res 19: 19-24, 2004.

PASCO JA, HENRY MJ, KOTOWICZ JA, COLLIER GR, BALL MJ, UGONI AM, NICHOLSON GC: Serum leptin levels are associated with bone mass in no obese women. J Clin Endocrinol Metab 86: 1884-1887, 2001. 
PATEL MS, ELEFTERIOU F: The new field of neuroskeletal biology. Calcif Tissue Int 80: 337-347, 2007.

REID I: Relationships among body mass, its components, and bone. Bone 13: 547-555, 2002.

REID IR, LUCAS J, WATTIE D, HORNE A, BOLLAND M, GAMBLE GD, DAVIDSON JS, GREY AB: Effects of a B-blocker on bone turnover in normal postmenopausal women: a randomized controlled trial. $J$ Clin Endocrinol Metab 90: 5212-5216, 2005.

RICCI TA, HEYMSFIELD SB, PIERSON RN JR, STAHL T, CHOWDHURY HA, SHAPSES SA: Moderate energy restriction increases bone resorption in obese postmenopausal women. Am J Clin Nutr 73: 347-352, 2001.

SATO M, TAKEDA N, SARUI H, TAKAMI R, TAKAMI K, HAYASHI M, SASAKI A, KAWACHI S, YOSHINO K, YASUDA K: Association between serum leptin concentrations and bone mineral density, and biochemical markers of bone turnover in adult men. J Clin Endocrinol Metab 86: 5273-5276, 2001.

SATO S, HANADA R, KIMURA A, ABE T, MATSUMOTO T, IWASAKI M, INOSE H, IDA T, MIEDA M, TAKEUCHI Y, FUKUMOTO S, FUJTA T, KATO S, KANGAWA K, KOJIMA M, SHINOMIYA K, TAKEDA S: Central control of bone remodelling by neuromedin U. Nature Med 13: 1234-1240, 2007.

SCHLIENGER RG, KRAENZLIN ME, JICK SS, MEIER CR: Use of beta-blockers and risk of fractures. JAMA 292: 1326-1332, 2004.

SIROTKIN AV, MLYNČEK M, MAKAREVICH AV, FLORKOVIČOVÁ I, HETÉNYI L: Leptin affects proliferation-, apoptosis- and protein kinase A-related peptides in human ovarian granulosa cells. Physiol Res

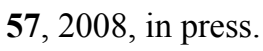

TAKEDA S, ELEFTERIOU F, LEVASSEUR R, LIU X, ZHAO L, PARKER KL, RMSTRONG D, DUCY P, KARSENTY G: Leptin regulates bone formation via the sympathetic nervous system. Cell 111: 305-317, 2002.

TARTAGLIA LA, DEMBSKI M, WENG X, DENG N, CULPEPPER J, DEVOS R, RICHARDS GJ, CAMPFIELD LA, CLARK FT, DEEDS J, MUIR C, SANKER S, MORIARTY A, MOORE KJ, SMUTKO JS, MAYS GG, WOOL EA, MONROE CA, TEPPERRI: Identification and expression cloning of a leptin receptor, OB-R. Cell 83: 1263-1271, 1995.

THOMAS T, BURGUERA B, MELTON LJ III, ATKINSKON EJ, O’FALLON WM, RIGGS BL, KHOSLA S: Role of serum leptin, insulin, and estrogen levels as potential mediators of the relationship between fat mass and bone mineral density in men versus women. Bone 29: 114-120, 2001.

THOMAS T, GORI F, KHOSLA S, JENSEN MD, BURGUERA B, RIGGS BL: Leptin acts on human marrow stromal cells to enhance differentiation to osteoblasts and to inhibit differentiation to adipocytes. Endocrinology 140: 1630-1637, 1999.

WANG X, RUNDLE CH, WERGEDAL JE, SRIVASTAVA AK, MOHAN S, LAU KHW: Loss of sex-specific difference in femoral bone parameters in male leptin knockout mice. Calcif Tissue Int 80: 374-382, 2007.

WARDLAW SL: Obesity as a neuroendocrine disease: lessons to be learned from proopiomelanocortin and melanocortin receptor mutations in mice and men. J Clin Endocrinol Metab 86: 1442, 2001.

WELT CK, CHAN JL, BULLEN J, MURPHY R, SMITH P, DE PAROLI AM, KARALIS A, MANTZOROS CS: Recombinant human leptin in women with hypothalamic amenorrhea. N Engl J Med. 351: 987-997, 2004.

YAMAUCHI M, SUGIMOTO T, YAMAGUCHI T, NAKAOKA D, KANZAWA M, YANO S, OZURU R, SUGISHITA T, CHIHARA K: Plasma leptin concentrations are associated with bone mineral density and the presence of vertebral fractures in postmenopausal women. Clin Endocrinol (Oxf) 55: 341-347, 2001.

ZHANG F, CHEN Y., HEIMAN M, DIMARCHI R: Leptin: structure, function and biology. Vitam Horm 71: 345-365, 2005.

ZHANG Y, PROENCA R, MAFFEI M, BARONE M, LEOPOLD L, FRIEDMAN JM: Positional cloning of the mouse obese gene and its human homologue. Nature 372: 425-432, 1994. 